\title{
O pensamento estético de Georg Lukács: continuidade ou ruptura?
}

Fecha de recepción: 4/8/2019. Fecha de aceptación: 19/8/2019.

\section{Resumo}

Ao longo de seu percurso intelectual, o filósofo húngaro Georg Lukács (1885-1971) demonstrou vasto interesse sobre a esfera artística, o que o levou a escrever duas estéticas. A primeira delas, redigida em dois momentos diversos de sua juventude, resultou em dois textos complementares, intitulados Filosofia da Arte (1912-14) e Estética de Heidelberg (1916-18). Dentre as influências que os textos apresentam, as mais marcantes são aquelas da filosofia neokantiana, da Lebensphilosophie e dos escritos de Hegel. A redação da segunda estética Lukácsiana veio a público em 1963 e foi pensada a partir da teoria marxista. Apesar de, aproximadamente, 45 anos separarem essas publicações, as indagações que Lukács colecionava acerca da esfera estética eram muito semelhantes, dentre as quais, citamos a preocupação do autor em elucidar o estatuto categorial particular do campo da arte no conjunto das criações humanas, a fim de garantir a autonomia da referida esfera. Diante de tais problemas, este estudo visa apresentar e discutir alguns pontos importantes das estéticas Lukácsianas para que seja possível respondermos à seguinte pergunta: É possível afirmar a existência de uma homologia entre as estéticas de juventude e de maturidade de Georg Lukács?

Palavras-chave: Estética; Georg Lukács; Marxismo; Lebensphilosophie.

Georg Lukács' Aesthetic Thought: Continuity or Rupture?

\author{
Abstract \\ Throughout his intellectual trajectory, the Hungarian philosopher Georg \\ Lukács (1885-1971) showed a particular interest in Art which led him to write
}


two aesthetics in different moments of his life based on different methodologies. His first aesthetics was composed by two texts, Philosophy of Art (1912-14) and Heidelberg Aesthetics (1916-18), which were mainly based on neo-Kantianism philosophy, on Lebensphilosophie and on Hegel's thoughts. The "Aesthetics" is Lukács' second project, which was published in 1963 and was based on the theory of Karl Marx. Although nearly 45 years separate these two projects, Lukács' questions about aesthetics were very similar, such as how to define, to describe and to consider the particular categorical status of Art in the set of human creations. Among these discussions, this study aims to present and to debate some important points from Lukács' aesthetics so that we could investigate a possible answer to the following question: Is it possible to conffirm the existence of a homology between the youth and maturity Georg Lukács' aesthetics?

Keywords: Aesthetics; Georg Lukács; Marxism; Lebensphilosophie.

\section{Introdução}

Ao longo de sua trajetória intelectual, o filósofo húngaro Georg Lukács (18851971) produziu estudos sobre os mais diversos assuntos, como estética, política ou ética. Dentre os temas abordados, a estética ocupou um lugar de destaque em seu pensamento, de modo que, em dois momentos diversos de sua trajetória, escreveu projetos estéticos apoiando-se em bases metodológicas distintas. A estética de juventude foi redigida em dois momentos diversos, resultando em dois textos complementares, intitulados Filosofia da Arte, escrita entre 1912 e 1914, e Estética de Heidelberg, composta entre 1916 e 1918. Dentre as diversas influências que os textos apresentam, as mais marcantes são aquelas da filosofia neokantiana, da Lebensphilosophie e dos escritos de Hegel. A segunda redação da estética Lukácsiana, cuja publicação da primeira parte se deu em 1963, foi pensada a partir da teoria de Karl Marx. Lukács, ao iniciar a estética de maturidade, na década de 1950, pretendia a redação de uma obra que consistiria em três partes, entretanto, finalizou, apenas, a primeira delas. Apesar de, aproximadamente, 45 anos separarem essas publicações, as indagações que Lukács colecionava acerca da esfera estética eram semelhantes. Dentre elas, pode-se citar a preocupação em elucidar o estatuto categorial particular do campo da arte no conjunto das criações humanas, de forma a garantir a autonomia da referida esfera. Em meio a tais questões, este artigo pretende expor aspectos centrais das estéticas Lukácsianas, analisando-os, a fim de que seja respondida a seguinte indagação: É possível afirmar a existência de uma homologia entre as estéticas de juventude e de maturidade de Georg Lukács?

Para empreender tal discussão, apresentaremos, em um primeiro momento, em linhas gerais, a fundamentação teórica das duas estéticas, as implicações que esses referenciais geram para cada um desses textos, bem como a noção de obra de arte para o jovem e o velho Lukács. Em um segundo momento, descreveremos de que modo o autor concebe o processo de criação artística em suas estéticas, observando as implicações desse entendimento para o campo da arte. 
Posteriormente, nos ateremos ao processo de recepção do objeto estético e, por fim, teceremos algumas considerações sobre o percurso estético lukácsiano, a fim de respondermos a pergunta que motivou a redação deste estudo.

\section{Lebensphilosophie e Marxismo: dois projetos estéticos em confronto}

As estéticas lukácsianas foram erigidas a partir de influências teóricas bastante diversas. Se, em sua juventude, Lukács adotou, fundamentalmente, as ideias da Lebensphilosophie para redigir os dois volumes que compõem a sua estética de juventude -Filosofia da Arte(1912-14) e Estética de Heidelberg (1916-18)-; na maturidade, o aparato conceitual do marxismo se impôs como fundamentação da "Estética” (1963). Cerca de quarenta e cinco anos transcorreram entre a redação das obras referidas e muitos acontecimentos históricos foram vivenciados por Lukács, de forma que a sua postura diante do mundo também se alterou substantivamente. Pensemos, à guisa de exemplo, sobre o seu ingresso, em 1918, no Partido Comunista húngaro, atitude que o aproximou da militância política. Se o escritor russo Máximo Gorki, no que tange à questão da criação artística, afirmou que uma obra de arte rica é, muito provavelmente, produto de uma vida igualmente rica, acreditamos que a trajetória intelectual de Lukács foi alimentada, também, por uma vida repleta de experiências; fator que, indiscutivelmente, reverberou no movimento de seu pensamento e nas posições que assumiu durante a sua vida. Partindo desse entendimento, acreditamos que a compreensão daquilo que vem a ser a obra de arte para o jovem e para o velho Lukács passa pelo entendimento e pela discussão da fundamentação teórica de suas estéticas. Nesse sentido, nos ocuparemos, por conseguinte, de uma breve exposição das influências teóricas presentes na Filosofia da Arte, na Estética de Heidelberg e na "Estética" (1963), para que possamos, assim, delinear as noções de obra de arte apresentadas nos textos referidos.

A estética de juventude apresenta um esquema em que a ideia de "vivência" (Erlebnis), segundo o nosso entendimento, é um dos elementos-chave para o entendimento do fenômeno artístico. Tal noção é um dos conceitos centrais da chamada Lebensphilosophie, tendência filosófica que, segundo o velho Lukács, pode ser definida como a ideologia dominante do período imperialista alemão, para a qual a vivência é entendida como o elemento que contém todas as categorias da realidade objetiva, o que nos motiva a afirmar que ela é a sua própria prova. Nesse sentido, a "vivência" se objetiva naturalmente e goza de uma estrutura hermenêutica, a saber, ela se auto-interpreta. A partir desse entendimento, é seguro afirmar que ela não é, somente, o seu próprio critério de verdade, mas a medida de todas as coisas. Transposta ao plano da arte, tal categoria é utilizada, dentre diversos outros aspectos, para que Lukács possa afirmar a autonomia do plano estético em sua estética de juventude, de forma que a "vivência" se torna responsável pela mediação da relação entre arte e subjetividade. Na esteira desse raciocínio, o reconhecimento do objeto estético não está ligado diretamente ao juízo na estética de juventude -ainda que este busque a transmissão de um 
sentimento que se supõe comum a todos os seres- mas, relaciona-se, antes, à "vivência" imediata da obra de arte. Em outras palavras, o sujeito estético -receptor ou fruidor-é aquele que vivencia o objeto e, não, aquele que o ajuíza.

Se, para Dilthey, um dos maiores expoentes da Lebensphilosophie, existe alguma possibilidade de conhecimento efetivo da realidade, ele se dará, por conseguinte, por meio da "vivência" e da vida. Para este mesmo filósofo, toda vida tem seu sentido próprio, que consiste, precisamente, em um nexo de significado. Para tal, é necessário o entendimento de que todos os homens possuem em si o Universo -como uma mônada leibniziana-, bem como são dotados da capacidade de lembrança; o que motiva Dilthey a afirmar que todo presente passível de lembrança possui um valor próprio. Depreende-se dessa noção, que há, simultaneamente, no nexo da lembrança, uma relação com o significado do todo, de forma que, a partir desse processo individual e altamente subjetivo, o sujeito extrai o sentido das suas "vivências", e, portanto, o sentido da vida, o que nos conduz a afirmar que estamos diante de uma tendência filosófica que entende que o mundo é construído pela "vivência": "vivência" objetivada como vida e vida subjetivada como "vivência".

O sujeito diltheyano, nesse sentido, é aquele que conhece o mundo a partir das percepções subjetivas que dele possui, o que nos leva a afirmar que a "vivência" determina, por conseguinte, as formas da realidade objetiva e, não, o contrário. A partir da fusão e da correspondência entre "vivência" e vida, a captação da essência da realidade passa a ocorrer por meio de um princípio irracional, o qual será responsável pela revelação dos elementos que se manifestam nas formas, nos princípios e nas categorias do pensamento; aspecto que invalida qualquer captação da realidade por meio de bases materiais do ser, como o trabalho. Ao trazer esse conjunto de noções para a esfera estética, as implicações são diversas. Dentre elas, ressaltamos que a fundamentação do objeto estético está ancorada na ideia de "vivência", o que implica afirmar que a obra de arte realizada é um receptáculo das "vivências" subjetivas do artista.

Para darmos conta dos desdobramentos dessa questão, é necessário o resgate do conceito de "realidade vivida" (Erlebniswirklichkeit), noção igualmente formulada pelos teóricos da Lebensphilosophie. Esse plano corresponde, segundo Lukács, à esfera da vida prática, cotidiana, em que os conteúdos aparecem de modo disperso e heterogêneo, ou seja, uma esfera onde o homem é muito mais possuído pela realidade que transcende sua consciência do que ele mesmo possui e domina essa realidade. Neste plano do "vivido" -que existe a priori das ações normativas da consciência-, as formas da consciência e os objetos se apresentam sempre fundidos e misturados, de modo indiferenciado, não permitindo qualquer diferenciação entre os objetos que existem no mundo. Sendo assim, a compreensão desse plano preconiza ao sujeito uma experiência de mundo de caráter absolutamente espontâneo, visto que o conhecimento teórico, o fato estético ou o plano ético não incidem na sua experiência com o mundo. A realidade vivida, portanto, "[...] cega o homem para os valores, para as objetivações humanas, embora essas constituam o mundo circundante e formem a base de todos os atos intelectuais e práticos do sujeito" (Patriota, 2010: 80); funcionando como um plano de reificação. 
Assumindo as noções de "realidade vivida" e de "vivência" como elementos centrais da estética de juventude, exporemos como Lukács entende a configuração da obra de arte. Para o autor, o objeto artístico condensa as vivências do artista e oferece aos homens a possibilidade de, nele, reviverem as suas "vivências" particulares do mundo, de um modo consoante às suas demandas subjetivas existenciais. $O$ mais agudo complicador dessa noção é que Lukács afirma que as vivências não são comunicáveis, pois o signo não dá conta de abranger o seu caráter vivencial, o que nos coloca, portanto, diante de um impasse. Desta feita, para o jovem Lukács, a obra de arte acaba por assumir a função de resgatar e reavivar o sentimento dos homens de pertencimento a uma comunidade humana perdida de outrora, aspecto absolutamente impossível de se realizar no plano da "realidade vivida", dada a conjuntura histórico-filosófica do mundo moderno. Para o sujeito estético, a obra de arte possibilita o resgate do desejo humano nostálgico de retorno a um plano em que sujeito e objeto se identificam plenamente.

Se, de alguma forma, retomamos a responsabilidade ou a função que a arte exerce na estética de juventude, temos de esclarecer, por conseguinte, de que modo ela pode ou tenta cumprir efetiva ou parcialmente essa demanda. No conjunto de noções envolvidas na estética de juventude, mundo empírico e mundo subjetivo raramente possuem pontos convergentes, o que configura uma visão solipsista que pressupõe uma disjunção metafísica entre vida empírica e sentido, caminhando, no campo estético, para a compreensão de que, se a realização humana autêntica e plena está vedada no plano da vida cotidiana, essa impossibilidade é compensada pela vivência oferecida pelos objetos artísticos, a partir dos quais é possível uma realização não estranhada dos valores humanos. De que maneira, portanto, essa possível realização pode ocorrer na esfera estética?

Para respondermos a essa questão, temos que resgatar a noção de forma artística, a qual se reveste, na estética de juventude, de um caráter místico, pois se torna o elemento capaz de reconciliar vida e essência, devolvendo um sentido à realidade. "À forma”, é predicado um caráter catalisador, de modo que ela se qualifica como uma força que introjeta um valor e um salto qualitativo na vida dos homens. Ela é traduzida, portanto, como a única realidade substancial que preenche de sentido um mundo humano carente de significado e insatisfatório às demandas existenciais dos sujeitos, embora, ressalte Lukács, que ela não supre a imediaticidade do plano da realidade vivida. Nesse sentido, essa realidade substancial traduzida pela forma é, sobretudo, a consciência de que a totalidade perdida de outrora é irrealizável na vida moderna. Depreende-se dessa noção a ideia de que a obra de arte fica impossibilitada de reparar a realidade objetiva e de resolver todas as dissonâncias do mundo burguês, pois seus próprios princípios constitutivos não lhe capacitam para tal.

Essa concepção de forma artística presente nos escritos de juventude de Lukács é originada por sua visão desesperançada e trágica do mundo moderno, o qual não oferece mais bases para uma relação plena de sentido entre sujeito e objeto. A reorganização e a reordenação dos conteúdos dispersos do plano da "realidade vivida" não são mais possíveis na esfera da vida cotidiana, de modo que 
a obra de arte, a partir do poder totalizante da forma, é o elemento que poderia reordenar, reorganizar e, portanto, dar sentido aos conteúdos caóticos do plano da vida cotidiana. Nesse sentido, o poder de harmonização da forma artística sobre o conteúdo anula qualquer contraposição entre ambos, configurando, por conseguinte, uma identidade perfeita de forma e conteúdo na totalidade intensiva que é a obra de arte. Entendemos, assim, que o material a ser plasmado no objeto só adquire sentido a partir desse poder metafísico da forma. Diante deste, o sujeito fruidor pode reviver os conteúdos de suas "vivências" de acordo com suas demandas existenciais. Esse movimento é definido pelo jovem Lukács como a superação ou a ultrapassagem da realidade da experiência vivida para a realização do vivido como vivido.

A forma, nesse sentido, realiza a harmonização e a realização ideal da alma humana, fazendo com que o plano de dispersão, caos e heterogeneidade da esfera da vida cotidiana, por meio da experiência estética, seja harmonizado; aspecto que possibilita a realização de uma experiência estética em que o receptor revive as suas experiências nos objetos materializados na obra de arte, os quais atendem suas demandas subjetivas. Concluída essa experiência, o caos e a dispersão, inerentes ao plano da "realidade vivida", são neutralizados, em um primeiro momento, pela experiência estética. Dessa forma, predica-se à obra de arte a expressão consolo transcendental. Entretanto, essa qualidade funciona, literalmente, como um alívio momentâneo, pois, se a possibilidade de uma comunicação eficaz da "vivência" no plano estético não é efetivada por completo, mas, somente, entrevista, segundo o jovem Lukács, o abismo que envolve a relação sujeito-objeto no mundo moderno é ressaltado e a ideia do solipsismo, portanto, acentuada, pois o homem não encontra, no plano da "realidade vivida", nenhuma possibilidade de "vivência" correspondente àquela elevada que gozou quando da experiência estética.

Se a estética de juventude é fundamentada por uma filosofia de bases idealistas, a Lebensphilosophie, o Lukács da maturidade adota um referencial diverso, pois, apoiado em bases materialistas, lança mão do aparato teórico da filosofia de Marx para construir a sua "Estética". A grande virada no pensamento lukácsiano, que marca a sua transição do idealismo objetivo para o materialismo histórico, reside no entendimento de que não são os sistemas que engendram a História, mas o contrário. Esta, portanto assume um papel demiúrgico, de forma que o devir histórico e o movimento das atividades do homem são vistos como fatores responsáveis por engendrar uma lógica determinada. O nosso ponto de chegada é, por conseguinte, a ideia de que o mundo e, consequentemente, a arte são, para o velho Lukács, criações materiais dos homens. Para dar conta dessa formulação, o autor se vale da categoria do trabalho, um dos conceitos centrais do materialismo histórico-dialético.

Marx afirma a prioridade ontológica do ser sobre a consciência, isto é, ele compreende que a realidade objetiva determina a consciência humana; conduzindo-nos à afirmação de que o momento fundador da organização dos homens não jaz no pensar, mas na produção. Por esse motivo, o trabalho, entendido como prática 
transformadora sobre a qual toda a sociedade se estrutura, torna-se uma das noções centrais para explicar a gênese do reflexo estético. Estamos, portanto, diante de um aparato conceitual que entende que, para cada momento histórico, há um determinado momento material a ele correspondente, o que equivale a dizer que o conjunto de valores ligado a certa quadratura histórica não pode ser compreendido em sua essência se privado do contexto que lhe deu origem. A partir desse conjunto de ideias, Lenin constrói a sua teoria do reflexo, afirmando que a consciência, o pensamento e as sensações humanas são reflexos da concretude do real na mente dos homens. Diante dessas noções, configura-se uma concepção materialista de mundo que entende que a realidade objetiva não é um mero dado exterior, pois o mundo social é uma criação dos homens, que é consciência.

Voltamos, assim, ao ponto que destacamos anteriormente: o mundo histórico e a arte são criações materiais humanas dotadas de sentido. Desta feita, os referenciais teóricos sobre os quais foram erigidas as estéticas levam o leitor a perceber a completa superação de Lukács das influências idealistas tão marcantes em sua juventude. $O$ contraste que buscamos ressaltar é o de que, na estética de juventude, se solidificou a ideia de que o mundo era construído a partir da ideia de "vivência", conduzindo-nos à noção da arte como criação do espírito. Na "Estética”, essa formulação é radicalmente superada, pois o mundo e a arte passam a ser entendidos como criações materiais dos homens; possíveis, somente, no decurso de um processo histórico evolutivo.

O velho Lukács investigará o movimento da subjetividade em direção à esfera estética, buscando compreender a origem do reflexo artístico. Para explicá-lo, afirma a necessidade da retomada do processo metabólico do trabalho, pois entende que, por meio dessa prática transformadora, as sociedades se organizam e se assentam. Consequentemente, as indagações acerca do mundo da arte devem ser aclaradas a partir do princípio de humanização do próprio homem, efetivado pelo trabalho. Diante dessa noção, Lukács afirma que o sujeito, ao se relacionar com os objetos do seu entorno, conhece e, por conseguinte, passa a dominar o espaço em que está inserido. Tal aspecto conduz o autor a uma ideia fundamental para a composição da "Estética", a de que o conhecimento de si do sujeito não acontece sem o conhecimento do conjunto das relações que ele trava com o mundo. Em outras palavras, assegura-se a correlação entre o ato de objetivação e o desenvolvimento da sensibilidade humana, o que, transposto à criação artística, acarreta na noção de que a conexão instituída entre o conhecimento de si e o conhecimento do mundo está na base do equilíbrio entre objetividade e subjetividade no processo de criação. À medida que o sujeito conhece o mundo e a si mesmo, ele passa a dominar o entorno, e, por decorrência, sente que o alheamento presente na sua relação com o mundo diminui. Este processo suscita uma relação entre sujeito e entorno em que o indivíduo passa a perceber o mundo como algo que lhe corresponde, que lhe é familiar, um mundo como pólis, como lar. Em decorrência desse movimento, Lukács afirma que o sujeito estético percebe a possibilidade da ampliação de sua personalidade na vivência artística. 
Essa evolução histórica inaugura um tipo de representação estética voltada à mundanidade, justificada pela noção de que, se o homem ampliou a sua práxis e o seu domínio intelectual sobre si e sobre o mundo; a resposta artística para tal conformação foi a origem da representação dos objetos vinculados indissoluvelmente ao espaço que os rodeia, materializando, no mundo da obra de arte, uma viva interação entre esses elementos. Lukács compreende, assim, que o objeto artístico é, portanto, expressão da vida humana, isto é, objetivação dos conteúdos humanos do homem. Daí, retomamos um ponto crucial no que tange à distinção das duas estéticas: a arte não é criação do Espírito, mas criação material dos homens.

As considerações precedentes deixam claro que a estética de maturidade compreende o processo de captação da realidade pelo artista de forma ativa. A este procedimento estão relacionadas particularidades históricas, como classe social, contexto cultural e histórico. Consequentemente, a fundamentação materialista da estética se ancora na concepção de que as produções ideológicas não podem ser autônomas em relação à práxis humana, isto é, os valores estão, sempre, historicamente determinados por um conjunto de forças materiais e por uma cultura determinada, de modo que as obras de arte podem ser explicadas, somente, a partir da totalidade sócio-histórica que lhes deu origem. A relação entre o objeto artístico e a História é, portanto, consolidada na visão do velho Lukács, o que nos conduz à afirmação de que objeto artístico assume a tarefa de plasmar os conteúdos humanos profundamente subjetivos e profundamente objetivos da vida, traduzindo-se em um objeto que compreende a projeção das tensões, contradições e características típicas latentes de um dado momento histórico. Estamos, por conseguinte, diante da teoria realista de composição artística, sistematizada por Lukács em seus escritos da década de 1930.

Encontramos, nesta ocasião, outro ponto de inflexão no que tange às estéticas deste autor: a obra de arte não é mais concebida como receptáculo de vivências subjetivas e atemporais, mas como reflexo real dos conteúdos humanos historicamente latentes de certa quadratura histórica. Soma-se a isso a filiação diversa das duas estéticas: na juventude, o autor entendia a "vivência" como categoria mediadora da relação entre subjetividade humana e arte, ao passo que, na maturidade, as noções de trabalho, História e reflexo são centrais para a compreensão da gênese artística e da relação sujeito-obra de arte. A partir dessa concepção, afirmamos que a noção de História está fora da estética de juventude, nos conduzindo a uma compreensão de mundo do jovem Lukács que carrega em si um caráter de atemporalidade. Desta feita, somos levados a afirmar que o mundo representado na obra referida não carrega o imperativo de que precisa ser mudado, já que é construído pela "vivência”. A obra de arte, como seu receptáculo, não envolve, portanto, nenhum caráter crítico no que tange à vida dos homens, ao passo que, na "Estética”, o objeto artístico, compreendido como reflexo da realidade, possibilita a compreensão da obra de arte como crítica da vida. Ao aderir ao materialismo histórico, Lukács passa a compreender a obra de arte como criação material dos homens, ancorada em um tempo histórico particular. Nesse sentido, 
a partir do momento em que os sujeitos passam a dominar o entorno e alargam o seu mundo externo e interno, desenvolvem o reflexo e a sensibilidade estética, construindo um mundo artístico que reflete os conteúdos humanos essenciais, da forma mais real possível.

Voltar-nos-emos, doravante, à ideia de forma artística presente na "Estética" de maturidade, mais um ponto que acentua, substancialmente, a divergência teórica do pensamento estético do jovem e do velho Lukács. Como afirmamos, as formações estéticas são entendidas pelo Lukács tardio como reflexos da realidade objetiva. A verdade e o significado dessas formações residem, essencialmente, na capacidade de tais reflexos de captar a realidade de modo fiel, reproduzindo-a em sua forma verdadeira, o que, consequentemente, evoca, no sujeito receptor, a imagem da realidade contida nesses reflexos. Para que esse processo ocorra, são compactados, na obra de arte, os conteúdos que serão por ela refletidos; processo intitulado redução homogênea. Decorre do potencial da forma artística a articulação de uma gama de conteúdos humanos que se traduzem na criação de uma totalidade orgânica e fechada. Lukács esclarece que a tarefa da forma artística, na "Estética", consiste, justamente, em tornar universalmente vivenciável um conteúdo substancial para a humanidade.

É necessário, por conseguinte, enfatizarmos a primazia do conteúdo sobre a forma na "Estética", esclarecendo que, somente um conteúdo intrinsecamente relacionado ao destino da humanidade, ou seja, um conteúdo substancial pode originar uma imputação de forma realmente profunda pelo artista. Resgatamos, desse modo, um princípio essencial da "Estética": o de que a forma é sempre a forma de um conteúdo determinado. Nesse sentido, nem o artista mais notório pode realizar a identidade de forma e conteúdo no objeto estético se essa relação é inexistente ou incipiente. Desta feita, a forma não é mais uma força geradora de sentido, pois os conteúdos dispostos no plano da vida cotidiana já são portadores de sentido; ela é, sobretudo, um recurso que materializa no objeto artístico os conteúdos essenciais da humanidade, fazendo com que o fruidor estabeleça uma relação desfetichizada com os conteúdos dispostos na obra. A História, ao entrar em cena na construção da "Estética", aniquila o caráter místico atribuído à forma nos escritos de juventude de Lukács, traduzido, essencialmente, pela ideia de que o objeto só ganha sentido a partir do momento em que recebe a forma. Esta, por sua vez, assume, para o velho Lukács, uma noção histórica, pois a quadratura histórica em que nasce a obra e de onde são retirados os seus conteúdos já demanda uma forma que emana desses mesmos conteúdos.

O entendimento do velho Lukács volta-se, portanto, à preponderância do conteúdo sobre a forma na "Estética", impulsionado, por conseguinte, pela ligação indissolúvel entre História e conformação artística; o que acarreta na ideia de que a vivência estética autêntica é uma vivência de conteúdo. Nesse sentido, a formulação da primazia da forma sobre o conteúdo, subjacente à Filosofia da Arte e à Estética de Heidelberg, corrobora, ainda mais, para intensificar as divergências teóricas entre essas obras. 


\section{A ideia de gênio na estética de juventude versus a ideia de criação artística na estética marxista ou a Aristocracia Espiritual versus o Homem Universal}

O processo de criação artística e o delineamento da figura do artista são temas caros a qualquer autor que pretende abordar questões relacionadas à estética. As obras de Lukács, por conseguinte, não se furtaram a essas discussões; pelo contrário, debateram-nas de forma consistente. Retomaremos, a seguir, os principais pontos relacionados ao processo de criação nas estéticas, para que verifiquemos como o jovem e o velho Lukács entendem essa questão.

A marcante influência da Lebensphilosophie na construção da estética de juventude privilegia a centralidade da intuição na criação artística, pois esta assume o papel de um novo órgão do conhecimento. A definição do termo está ligada à ideia de uma revelação súbita da consciência subjacente a um processo de pensamento que, até então, se desenvolvia no âmbito do inconsciente, procedimento que encontra certa equivalência à noção de êxtase presente no movimento barroco. De acordo com alguns autores da Lebensphilosophie, para que a compreensão de algum fenômeno fosse possível, argumentava-se em favor da ideia de que algo irracional emanava de todo ato de compreensão, como a própria vida, que não podia ser representada por nenhuma classe de formas de ordem lógica. Consequentemente, o ato de compreensão assumiu, no interior dessa tendência filosófica, um caráter adivinhatório, irracional; desdenhando de qualquer possibilidade de obtenção de uma certeza demonstrativa, pois a vivência recriada, intrínseca ao processo de compreensão, não era entendida como suscetível a exames de valor no que tangia ao conhecimento. No âmbito estético, a Lebensphilosophie susteve a ideia de que a interpretação, apreendida como um compreender recriador, carregava em seu seio um caráter genial. Desse conjunto de noções, depreende-se uma psicologia responsável pela construção e fundamentação daquilo que pode ser chamado de doutrina secreta de uma determinada aristocracia espiritual estético-historicista.

As influências teóricas presentes na estética de juventude resultam, assim, no sujeito do individualismo metodológico, que descarta a ideia de captação do real. Lukács, ao invés de explicar o indivíduo por meio de sua interação e de seu posicionamento numa sociabilidade, centra-se no sujeito do individualismo metodológico e se volta para a compreensão de seu interior, no intuito de explicar por qual motivo o mundo vivenciado se configura de determinada maneira. Esse sujeito não tem vínculos com a História e é concebido a partir de certo caráter atemporal. Estamos diante de um indivíduo que porta em si uma habilidade inata de transposição dos conteúdos de sua subjetividade -inconscientes (forma da experiência)- a partir da utilização de uma forma técnica adequada -momento consciente. Segundo Lukács,

no gênio, os dois momentos, a clareza consciente e o momento inconsciente, constituem os princípios que de tempos em tempos prevalecem, mas que estão sempre presentes (isto é, a comunhão da forma da experiência e da forma técnica é a condição apriorística do processo criativo) (Lukács, 1973: 173). 
Esse procedimento revela, gradativamente, a busca de uma objetividade que se realiza na criação da realidade objetiva e autossuficiente da obra de arte, originando, na composição do objeto, uma realidade superior, denominada por Lukács utópica.

Nesta realidade, a técnica e a visão -esta compreendida como resultado do domínio dos conteúdos inconscientes pela técnica formal-devem, ambas, perder o seu caráter subjetivo. Por esse motivo, Lukács afirma que, na realização da obra de arte, a técnica formal deve se tornar natural e invisível. Já, a visão, identificada à obra concluída, tem de perder todo o seu significado com e no objeto acabado, de maneira que deve apontar indicadores ao artista que, em seu trabalho técnico, necessariamente subjetivo, lhe conduzam à objetividade. A visão deve ser, por conseguinte, a garantia de que a técnica como tal se dissolverá na obra realizada. Desta feita, o gênio, diante da criação do objeto, é aquele que reconhece a necessidade da harmonia praestabilita entre a técnica artística e o conteúdo, realizando-a na composição da obra de arte.

Em Filosofia da Arte e Estética de Heidelberg, o artista era compreendido por Lukács como gênio, como um ente contemplado pela capacidade inata de dação de forma aos objetos de sua vivência, a fim de que pudesse recriá-las e plasmá-las no mundo fechado da obra de arte. Essa afirmação nos conduz, portanto, à ideia de uma aristocracia espiritual na estética de juventude, voltada ao entendimento de que só alguns espíritos elevados recebem esse dom natural, possibilitando, por conseguinte, a compreensão de que o desenvolvimento do espírito caminha de forma independente ao da realidade. Essas considerações demarcam mais um aspecto que restringe as estéticas Lukácsianas a campos teóricos diversos, pois a polarização entre a ideia de uma aristocracia espiritual, na estética de juventude, e a noção de homem universal, presente na "Estética", revela o quão distantes são as visões de mundo do autor subjacentes a essas obras. Prosseguiremos apresentando os aspectos que demarcam essa divergência.

O velho Lukács não mede esforços para criticar a ideia da intuição como instrumento do conhecimento ou como elemento constitutivo do conhecimento científico, de modo que ela é considerada, somente, um complemento do pensamento intelectual e, de forma alguma, a sua síntese. Consequentemente, a descoberta intuitiva de uma conexão não institui jamais um critério de verdade ou de aproximação à objetividade, pois, para o autor da "Estética", é a verdadeira dialética o instrumento capaz de expressar, pela via conceitual, o reflexo exato dos objetos presentes no mundo real. A partir desse conjunto de noções e assentado sobre as bases da filosofia marxista, Lukács assegura que a obra de arte tem como ponto de partida a existência de uma realidade objetiva, que, por si só, é capaz de fornecer verdades acerca de um indivíduo concreto cuja sociabilidade é histórica e socialmente condicionada.

Lukács institui, assim, o realismo como composição artística, definindo-o como a inevitável consequência do reflexo artístico da realidade e como uma tomada de posição do artista diante do real. Nesse sentido, a missão do sujeito criador está 
relacionada à imitação da vida na obra de arte, o que imputa ao artista a missão da construção de uma totalidade intensiva que reflita a realidade de modo justo e fiel. $O$ mundo da obra de arte deve ser estruturado de forma concreta e, também, sensível, fazendo com que a obra exponha um conjunto de conteúdos humanos que ultrapassa o plano habitual da percepção cotidiana. A arte, portanto, tem uma missão desfetichizadora, pois representa situações essenciais do desenvolvimento humano, revelando as contradições inerentes ao processo social evolutivo. Nesse sentido, as situações e os caracteres representados pelo artista são reflexos da realidade que revelam situações criadas pelos homens e não circunstâncias próprias de uma condição humana a-histórica; o que possibilita aos receptores a percepção dessas situações e, portanto, a sua superação. Entende-se, destarte, que a obra de arte tem uma função social, assumindo, por sua vez, o papel de crítica da vida:

[a] arte ou é desfetichizadora ou não é arte. A isso Lukács chama realismo: em sua missão desfetichizadora, a arte representa situações de opressão, de degradação da humanidade do homem, mas as personagens aí representadas podem perceber essas situações como situações criadas pelos homens, não como próprias de uma condição humana antistórica, e se assim as percebem, percebem também as possibilidades de superá-las (Bastos, 2016: 48).

Frente às afirmações precedentes, podemos assegurar que a noção aristocrática e irracionalista de gênio presente na estética de juventude é superada na "Estética", pois o artista não é mais compreendido como um ente alheio à necessidade social da arte. Exige-se dele a elevação de sua subjetividade para além da imediaticidade do plano da vida cotidiana, a fim de que capte as tendências e contradições essenciais de um tempo historicamente e socialmente determinado, plasmando-as na obra. Para que esse processo seja exitoso, demanda-se do artista uma seleção adequada de temas, de situações, de figuras e de comportamentos típicos observados na realidade. Esses conteúdos tornarão rica a matéria para a composição da obra de arte e deles emanará a forma artística adequada e correspondente, que vem à tona a partir de um processo de elaboração do conteúdo pelo artista. Desse novo entendimento em relação à figura do artista, depreende-se que a substancialidade da obra se vê em uma relação de dependência com o sujeito criador, traduzida pelo reconhecimento em si do artista da substância humana concreta. Ele é, portanto, quem capta as tensões essenciais do processo social em que está inserido e as reflete do modo mais fiel possível na obra de arte; o que denega a ideia do objeto estético como um receptáculo de vivências.

O debate encaminha-se, assim, para a noção do partidarismo na criação artística. Para Lukács, não existe arte neutra, pois o processo de criação em si já consiste em uma tomada de partido do artista frente aos conteúdos da realidade que ele se propõe a figurar. Não se deve recair, portanto, na ideia de partidarismo como literatura panfletária ou como desvio politicista, devendo-se ter em mente, sobretudo, o fundamento ético intrínseco ao ato de composição. Precisamos lembrar que o autor foi um crítico da arte puramente panfletária e publicista, de modo que, se é imputada ao artista a missão de refletir as tensões sociais, é necessário que, ao desempenhá-la, ele o faça sem pré-julgamentos, e que, ao mesmo tempo, 
se porte diante do objeto a ser representado de forma interessada. Essa afirmação traduz-se na ideia de que o artista deve alcançar uma proporção justa e equilibrada entre a liberdade de criação e a necessidade social da arte.

Lukács busca, portanto, o entendimento do artista como alguém cujo papel consiste em construir um mundo estruturado de forma a reproduzir fielmente a realidade, mesmo que os seus próprios conteúdos individuais -crenças políticas, valores, ética-estejam em total desacordo com as situações típicas que pretende plasmar na obra. Ainda sobre essa questão, o autor afirma que a relação entre o sujeito criador e o mundo deve ser rica, pois esse indivíduo deve refletir na obra um mundo do qual ele faz parte e um mundo que ele mesmo comporta em sua subjetividade. $O$ artista autêntico tem que intensificar a unidade entre o externo e o interno, percebendo, pensando e sentindo o interno e o externo em sua unidade; procedimento que o permite alcançar a substancialidade estética. 0 que estamos pontuando é a noção de um sujeito que alcança um grau elevado de autoconsciência de si do gênero humano no momento da criação artística, pois entra em contato com conteúdos humanos essenciais, que passam a uni-lo aos feitos passados e presentes da humanidade, de forma que conteúdos exteriores a ele se fundem ao seu núcleo humano, formando, assim, uma unidade.

A figura do artista autêntico na "Estética" é, de acordo com o nosso entendimento, a do artista realista, conduzindo-nos à percepção de que esse sujeito tem o seu mundo interior alargado e enriquecido ao realizar o processo de composição, pois plasma, na obra, uma realidade superior, desfetichizada e não estranhada, que se incorpora ao seu mundo subjetivo. Ao materializar feitos humanos, destinos, figuras e situações típicas na obra de arte e, ao lançá-la ao mundo dos homens como um objeto que adquire existência concreta e autônoma, Lukács, consequentemente, constrói um perfil para o artista cuja responsabilidade social está vinculada a ele próprio, mesmo que ele não possua tal intenção. Nesse sentido, é dever do artista

se rebelar contra o sistema manipulador e dar aos homens, com suas obras, uma esperança mínima, uma perspectiva, ainda que individual. Perspectiva que o artista põe a descoberto na medida em que afirma criticamente a vigência do humano na história e no presente reificado, na medida em que suas criações dão vida a sentimentos autênticos, os quais, não importando o quão raro estes possam ser, constituem-se como possibilidades intrínsecas do ser social (Patriota, 2010: 264).

A partir da exposição sobre o processo de criação das obras de arte nas estéticas, concluímos que há uma acentuada divergência sobre o entendimento da figura do artista nessas obras. A síntese dessa dissensão pode ser resumida pela formulação, na estética de juventude, de um sujeito do individualismo metodológico, o qual faz parte de uma aristocracia espiritual, ao passo que, na estética de maturidade, o artista passa a ser entendido como homem universal. Se aquele desenvolvia o espírito de forma praticamente independente da realidade, o sujeito da "Estética" o faz a partir de sua relação com o mundo, com a realidade. Essas noções, caras à ideia de criação artística, são essenciais para a compreensão da experiência receptiva, tema que exploraremos a seguir. 


\section{Fenomenologia da recepção, mal-entendido (MiBverständnis) e incomunicabilidade da vivência versus experiência receptiva e catarsis}

Em Filosofia da Arte, o jovem Lukács nega a possibilidade da comunicação efetiva dos conteúdos essenciais e singulares das vivências dos indivíduos no fenômeno de recepção da obra de arte. Como motivos dessa impossibilidade, afirma-se que, por mais que os meios expressivos suscitem no receptor a ilusão do retorno nostálgico a uma comunidade humana, esse fenômeno é puramente aparente, pois os meios expressivos -como os gestos ou a entonação, sem a mediação das palavras- não conjugam as determinações e não dispõem de contornos suficientes para efetivar o processo comunicativo. Soma-se a isso, segundo Lukács, a impossibilidade de se "encontrar a garantia de comunicar a peculiaridade subjetiva daquilo que é diretamente vivenciado" (Lukács, 1973:32). A dissensão entre signo e coisa é um dos traços que marca a impossibilidade da comunicação da experiência individual, pois o signo é compreendido, segundo o jovem Lukács, como algo abstrato, uma redução incapaz de captar a qualidade particular daquilo que é mais essencial, bem como não dá conta de abranger o caráter vivencial da "vivência".

O autor afirma, ainda, que os meios comunicativos podem falsear os sentimentos e os humores do indivíduo, de forma que não se pode afirmar se a intensidade de uma mensagem expressiva é um elemento confiável no julgamento da autenticidade de seu efeito, pois este pode ser gerado tanto pelos meios expressivos quanto pela "vivência". Outro ponto a ser levado em conta é a noção de que a expressão, por mais verdadeira que seja, pertence ao receptor e, não, ao artista, pois é aquele que se apropria e que apreende o conteúdo transmitido por este. É o fruidor, portanto, que mobiliza suas vivências e experiências singulares, reelaborando subjetivamente o material transmitido pelo artista e tolhendo aquilo que não está de acordo com as suas "vivências". Se estas são projeções do próprio sujeito na realidade e são condicionadas pelo outro; o receptor pode, somente, vivenciar no objeto as características que se relacionam à sua estrutura individual.

Lukács afirma, por conseguinte, que o processo de recepção artística é marcado por um mal-entendido (MiBverständnis), caracterizado pela não captação e não absorção do sujeito fruidor daquilo que seria o verdadeiro conteúdo substancial da obra de arte. Nesse sentido, esse indivíduo, que encerra em si suas "vivências", alcança o entendimento de que seus conteúdos subjetivos individuais não são comunicáveis, semelhantes ou equivalentes àqueles alcançados no mundo fechado do objeto artístico. Desse movimento, depreende-se que as demandas do fruidor de adequações do mundo diante de sua realidade, postuladas pela obra, podem, apenas, se tornar conscientes como conteúdos que não coincidem àqueles substanciais plasmados no objeto; repercutindo em certa autonomia do comportamento desse sujeito frente à abra de arte. A vivência artística é, portanto, reafirmada como um mal-entendido (MiBverständnis), pois, no processo de recepção, o fruidor não encontra a subjetividade do sujeito criador, não realizando, assim, o seu desejo de retorno nostálgico a uma comunidade humana onde a 
comunicação pode ser plenamente realizada. Como mencionamos, o receptor encontra, somente, uma subjetividade autônoma. Desta feita, o solipsismo não pode ser superado na estética do jovem Lukács, o que não invalida, entretanto, $o$ entendimento da experiência artística como consolo transcendental, noção que será combatida e abandonada por completo na "Estética".

Para o velho Lukács, o homem conhece a si mesmo à medida que conhece e domina o mundo à sua volta, ambiente onde ele tem de viver e agir. Ao ampliar esse domínio, surgem as obras de arte, que, de acordo com o entendimento do autor, devem refletir de forma justa os conteúdos essenciais da realidade objetiva. A partir dessa compreensão, a experiência receptiva é descrita como um processo em que o fruidor se coloca diante de uma totalidade intensiva que reflete conteúdos humanos essenciais de maneira verdadeira, nos levando a afirmar o caráter profundamente humanístico da experiência estética. Soma-se a isso a noção de uma experiência receptiva calcada em uma relação sujeito-objeto em que o fruidor capta e absorve conteúdos humanos que dizem sobre o seu mundo e sobre toda a evolução humana. Nesse sentido, a consciência desse homem é alargada e enriquecida na experiência receptiva, proporcionando ao sujeito fruidor a autoconsciência de si do gênero humano, de modo que ele se vê parte de uma universalidade: a humanidade. Embora Lukács entenda essa experiência como um processo que estimula o ser a conhecer aquilo que o rodeia -os seus semelhantes, a sociedade em que vive, a natureza, o seu campo de ação, dentre outros aspectos-, o autor afirma, ainda, que essa experiência coloca o fruidor diante da compreensão dos estratos mais profundos do seu próprio ser; realização que nunca poderia ser impetrada pelo sujeito a partir de uma "pura" investigação de si próprio. Apontamos, assim, não apenas para um enriquecimento desse homem em relação aos conteúdos que povoam o seu entorno, mas, também, para um enriquecimento de seus conteúdos interiores; o que aponta para a experiência receptiva como um processo de autoconhecimento.

Além dos aspectos descritos, a vivência estética permite ao fruidor a evocação da memória da humanidade, visto que, de acordo com Lukács, a obra de arte é sua portadora, pois materializa os conteúdos que ampliam, enriquecem e aprofundam a noção de homem e suas relações com o entorno e com o gênero. A fruição é, consequentemente, um fenômeno que coloca o sujeito frente aos destinos típicos já vividos pela humanidade, de modo que podemos nos conectar a eles e revivê-los nos objetos estéticos; esse movimento possibilita uma recepção artística em que o sujeito incorpora os caminhos passados e presentes da humanidade bem como a consciência dos homens que realizaram essas trajetórias. Ao fruidor, portanto, é ofertada a possibilidade de participação efetiva na vida da humanidade. Sobre esse movimento, também é necessário ressaltar a ideia de que a fruição possibilita a transformação de um passado espacial e temporal em um momento presente vivido, despertando, no receptor, a consciência de viver em um mundo do qual ele faz parte e do qual é co-criador.

A recepção artística tem de resultar, segundo Lukács, em uma transformação do sujeito fruidor de homem inteiro em homem inteiramente, orientado para 
a universalidade de um meio homogêneo. 0 conteúdo humano dessa transformação envolve uma suspensão do sujeito do plano da vida cotidiana, de forma que se estabeleça um tipo de relação com a obra de arte cuja marca é um comportamento receptivo que, imediatamente, acolhe o objeto da contemplação. As tendências ativas do homem e a sua vontade de intervir nos dados concretos do mundo permanecem suspensas, o que faz com que Lukács observe um traço passivo no comportamento receptivo; ao passo que, no processo de criação artística, aponta para o domínio do princípio ativo, demarcado por uma transformação gradual dos conteúdos essenciais da vida em identidade de forma e conteúdo.

A fim de que se efetive a transformação do homem inteiro em homem inteiramente, é necessário que o meio homogêneo penetre na vida anímica do receptor, orientando e evocando as suas vivências no momento da fruição. À ocasião, sua forma habitual de contemplar o mundo é subjugada, pois a obra coloca esse sujeito diante de um mundo novo, dotando-o de novos conteúdos e lhe ofertando uma nova maneira de concebê-los. A implicação dessa experiência é a recepção e apropriação pelo sujeito estético de um mundo com sentidos renovados, ou seja, a sua psique se amplia e se enriquece a partir da captação desses novos conteúdos; processo que resulta na catarsis.

Semelhante às demais categorias estéticas, a catarsis, para Lukács, tem sua origem primária na vida e, não, na esfera artística. Nesse sentido, ela é percebida como um momento constante e significativo da vida social dos homens. Ao entendermos a obra de arte como uma refiguração dos conteúdos essenciais da vida humana e ao identificarmos a origem da catarsis nessa mesma vida, é assegurada uma correspondência entre as categorias estéticas e àquelas subjacentes à vida humana. Lukács define a catarsis como um reflexo concentrado e conscientemente produzido de comoções. Na esfera da vida cotidiana, ela se dá espontaneamente e ocorre concomitantemente aos episódios que permeiam a vida humana, ao passo que, no plano estético, ela se traduz quando, ao entrar em contato com o objeto estético, o fruidor percebe, na refiguração do mundo fechado da obra de arte, a reprodução de uma realidade elevada e superior, que é plasmada de forma a permitir ao receptor um contato com um mundo que tem como marca a desfetichização dos conteúdos essenciais da vida humana. Em outras palavras, essa elevação do mundo fetichizado a um mundo verdadeiramente humano é a experiência da catarsis, por meio da qual o receptor se humaniza.

De acordo com Lukács, a imediaticidade própria da esfera estética, quando comparada à da vida cotidiana, é uma imediaticidade superada, pois se abre a possibilidade da figuração de conteúdos gerais e essenciais da evolução humana, os quais sofrem um processo de seleção, depuração, hierarquização e redução, para que possam, assim, ser recebidos pelo sujeito fruidor. É justamente nesse sentido que o mundo fechado da obra de arte é elevado e superior, pois é um mundo de caráter verdadeiramente humano, revelado, por conseguinte, pela experiência catártica, que proporciona a humanização do sujeito estético. A catarsis, portanto, dá sustentação à missão desfetichizadora da arte ao revelar ao sujeito a 
fetichização subjacente à vida cotidiana. Consequentemente, a possibilidade de defesa da integridade da humanidade no plano da vida cotidiana torna-se real e objetiva, o que faz da obra de arte um veículo pedagógico, pois a relação sujeitoobjeto possibilita ao receptor a percepção "natural" de alguns aspectos da vida, que, no plano disperso da cotidianidade, ficam obscurecidos.

Esse entendimento nos conduz a uma compreensão da fruição artística como defesa da integridade da humanidade no plano da vida cotidiana e como crítica da vida, pois é aberta uma via para que o sujeito estético possa transformála no mundo real. Diante dessa compreensão, a desfetichização e a catarsis possibilitam à arte realista a realização de um papel fundamental na formação humana, pois reconcilia o sujeito com o mundo do qual ele se separou. Ao refigurar os conteúdos essenciais da realidade no mundo fechado da obra de arte, e ao criar um mundo elevado e superior, o fruidor passa a se reconhecer no mundo dos objetos, o que assegura a possibilidade da aproximação e, até mesmo, da identidade sujeito-objeto negada pelo trabalho estranhado e fetichizante.

A experiência estética possibilita, portanto, a não rendição do sujeito à fetichização e à alienação impregnadas no plano da realidade cotidiana, pois, ao se reconhecer no mundo dos objetos e ao se sentir parte desse mundo, o sujeito estético entende-se como seu co-criador, restabelecendo, por sua vez, a relação então rompida entre o homem inteiro e o homem inteiramente. Diante dessas possibilidades, a arte se apresenta como um meio para que o indivíduo, ao retornar à vida cotidiana enriquecido pela experiência estética, possa construir uma relação sujeito-objeto autêntica. Como mencionamos, a experiência catártica conduz o sujeito fruidor a viver o mundo como a sua pátria, pois ele se reconhece como seu co-criador e como parte do gênero humano. Consequentemente, se reconhece, ainda, como parte de todas as conquistas e de todos os feitos históricos da humanidade. A partir dessa experiência, ele experimenta a sua condição como homem universal, como parte da humanidade, sem que seja necessário o aniquilamento de seus traços mais singulares. Segundo Lukács, a experiência estética:

[...] não se reduz, por conseguinte, a mostrar novos aspectos da vida ou a iluminar com novas tonalidades aspectos já conhecidos pelo receptor, mas a novidade qualitativa da visão que assim nasce altera a percepção e a capacidade e a torna apta para a percepção de novas coisas e de objetos habituais a partir de uma nova iluminação, de novas conexões e de novas relações de todas essas coisas com ele mesmo. (Lukács, 1972: 528).

Esse conjunto de noções nos faz compreender a recepção artística como uma experiência em que o sujeito pode atravessar e superar a barreira da alienação, de forma a realizar a crítica e a transformação de sua existência e das relações que estabelece com o mundo. Essa retroação da vivência estética, a qual incide sobre a subjetividade ativa do cotidiano dos homens, é uma das mais importantes implicações da catarsis no que tange ao caráter social da arte. 
A partir da "Estética" de maturidade, Lukács encontra uma zona compartilhada entre a estética e a ética, cujo ponto de convergência se dá a partir do entendimento Lukácsiano da catarsis como uma vivência da realidade intrínseca da vida humana, cuja comparação com a realidade da vida cotidiana produz, devido ao efeito da obra, uma purificação das paixões que se converte em ética já no momento posterior à fruição artística. Este Depois abre a possibilidade ao sujeito fruidor de uma possível transformação existencial direcionada à realização de possibilidades humanas autênticas, mais significativas, ricas e amplas. A vivência estética evoca, assim, a possibilidade de um desenvolvimento humano em que o sujeito, sem apagar a sua singularidade, reivindica para si as tarefas do gênero humano, vivenciando-as como suas e compreendendo os traços comuns da vida do gênero e de sua própria existência. 0 entendimento da eticidade apontará, segundo Lukács, para a harmonização dos interesses genéricos e particulares do indivíduo, de forma que suas tomadas de decisão terão como referência a sua própria generidade, mas orientadas, sobretudo, pela sua superação.

A partir dessa breve descrição da recepção artística nas duas estéticas Lukácsianas, percebemos uma mudança marcante do entendimento de seu autor sobre a questão, pois a arte deixa de ser concebida como a satisfação interior de um desejo humano que jamais se efetiva na vida prática dos homens. 0 objeto artístico passa a ser entendido, sobretudo, como a expressão de uma realidade que, embora transcenda os horizontes de vida usuais do indivíduo, aponta para a concreção de possibilidades humanas reais. É importante ressaltarmos que, mesmo as obras que versam sobre tempos remotos, ou aquelas já situadas em um tempo histórico longínquo do receptor, como o romance histórico ou as tragédias, propiciam uma vivência estética objetiva, no sentido de que propõem ao fruidor um resgate rememorativo de alguma experiência universal situada em um tempo histórico particular. Desta feita, afirmamos que o intuito da experiência receptiva não está centrado, como na estética de juventude, na recordação do que se perdeu no passado ou na satisfação do desejo humano nostálgico de se sentir parte de uma comunidade que resgata uma relação sujeito-objeto idêntica de tempos idos. O abismo transcendental e intransponível entre obra e objetividade que fundamenta a ideia de que a vivência é incomunicável na estética de juventude é, portanto, superado na "Estética", pois a vivência propiciada pela arte deixa de ser algo fechado sobre si mesmo e se abre para a vida real do sujeito estético, para o qual é imposto o desafio do Depois da experiência receptiva.

\section{Considerações finais}

Após a análise de alguns pontos centrais das estéticas de juventude e de maturidade Lukácsianas, concluímos estarmos diante de dois textos cujas matrizes teóricas são definitivamente diversas. De certo, existe uma continuidade temática, isto é, Lukács retoma, no seu pensamento estético tardio, temas já discutidos na juventude, entretanto, é importante ressaltar que essa continuidade temática não se traduz em um tratamento comum aos temais fundamentais ligados ao 
estudo da estética. A definição de obra de arte, a sua criação, a sua recepção e a sua função no mundo dos homens são aspectos entendidos de forma radicalmente diversa nos textos analisados, o que nos conduz a afirmar que não há uma homologia ou uma continuidade entre as estéticas Lukácsianas, mas um rompimento radical do Lukács maduro em relação àquele da juventude. Sistematizaremos, portanto, pontos centrais dos textos analisados, que apontam para a ruptura mencionada.

Em Filosofia da Arte e Estética de Heidelberg, a matriz Lukácsiana foi influenciada, essencialmente, pela teoria de Kant e por filósofos da Lebensphilosophie, o que conduziu o autor a afirmar que o mundo cotidiano, ou seja, a esfera da vida prática, da "realidade vivida", é construída pelas "vivências" subjetivas dos homens, de forma que a arte, que é criação do espírito, é compreendida como um receptáculo de "vivências" e funciona para os sujeitos como um consolo transcendental. $\mathrm{Na}$ "Estética", a matriz do autor é radicalmente diversa, pois, a adesão ao marxismo, conduz ao entendimento de que o mundo é criação humana, logo, a arte é produto material dos homens e reflete de modo justo e fiel o seu mundo. Sua missão é a desfetichizadora e o efeito de sua recepção é a transformação do homem inteiro em homem inteiramente. Diante desse conjunto de informações, depreendemos, ainda, que a arte funciona como um instrumento pedagógico e como crítica da vida para o velho Lukács, ao passo que o mundo não precisa ser mudado na sua estética de juventude, pois o sujeito se realiza na realidade utópica da obra de arte, de forma que o desenvolvimento de seu espírito independe da realidade objetiva e histórica. No extremo oposto, está o sujeito apresentado na "Estética”, pois a sua realização se dá em um tempo e espaço determinados do plano da vida cotidiana. Nesse sentido, temos o confronto entre dois tipos de sujeito esboçados: aquele que é pensado a partir da ideia de Aristocracia Espiritual e aquele entendido por meio da noção de Homem Universal.

Concluímos que, na estética de juventude, a relação entre arte e vida cotidiana está marcada por um distanciamento, pois o sujeito fruidor, embora tente se realizar na realidade utópica da identidade sujeito-objeto configurada no mundo da obra de arte, não alcança tal realização no mundo objetivo. Esse fracasso, marcado pela noção de mal-entendido (MiBverständnis), ressalta o abismo transcendental que subjaz a relação sujeito-objeto no plano caótico da vida cotidiana. Desta feita, a vivência artística funciona como um consolo transcendental, pois o sujeito entra em contato com possibilidades mais autênticas e potentes de vida no mundo da obra, mas está impossibilitado de realizá-las na sua vida material, fator que ressalta a noção de solipsismo, pois o sujeito se volta à sua subjetividade, impossibilitando um fluxo metabólico entre os planos da arte e da vida cotidiana. Entendemos, portanto, que, na estética de juventude, há um distanciamento entre os planos mencionados. De modo diverso, compreendemos a relação entre arte e vida na "Estética", pois concluímos que há uma aproximação entre tais planos. Para justificar essa afirmação, é necessário resgatar o que Lukács entende pelo Depois da experiência receptiva das obras de arte. Para o autor, o sujeito fruidor se conecta com as experiências passadas, presentes e com as perspectivas futuras do gênero humano ao entrar em contato com o objeto estético, 0 
que lhe proporciona a transformação do homem inteiro em homem inteiramente, passando por um processo em que o sujeito alcança a autoconsciência de si do gênero humano. Desta feita, a vivência estética e também a obra de arte podem ser entendidas com um instrumento de crítica da vida.

Nesse mesmo sentido, podemos dizer que a obra de arte e a relação que o sujeito com ela estabelece adquirem um caráter pedagógico, pois, ao absorver um alto teor de conteúdo humano, o sujeito estético pode reorientar as suas práticas sociais no instante Depois da experiência receptiva. Se o Depois possibilita ao receptor uma transformação existencial orientada à realização de possibilidades humanas autênticas e significativas, a fruição pode apontar para um desenvolvimento humano em que o sujeito, sem se despir de suas singularidades, toma para si as tarefas do gênero humano, pois a obra de arte permite que ele as vivencie. Afirmamos que, neste momento, as esferas da arte e da vida cotidiana se entrecruzam, pois, se o mundo das autênticas obras de arte, ou seja, daquelas realistas, exige o recurso da tipicidade, ou seja, se as personagens e as situações refiguradas no objeto figuram trajetórias individuais conectadas e orientadas à generidade, a vivência estética pode assinalar ao fruidor um entendimento da eticidade que aponta para a harmonização dos interesses genéricos e particulares do indivíduo, de modo que suas tomadas de decisão no plano da vida cotidiana assumirão como referência a sua própria generidade, mas orientadas, sobretudo, pela sua superação. Estamos, portanto, diante de um sujeito que tem o potencial de orientar as suas práticas sociais para o bem comum. Identificamos, aqui, a relação de aproximação entre arte e vida, pois o homem, enriquecido pela experiência receptiva, pode trazer para o seu mundo todos os conteúdos que ele foi buscar na obra e, por conseguinte, trouxe para dentro de si no momento da fruição estética, assegurando a possibilidade do fluxo metabólico entre os planos da vida e da arte.

A partir das considerações que tecemos até o momento, somos levados a afirmar que as matrizes teóricas de que Lukács dispunha à redação de suas estéticas são elementos fundamentais para analisarmos e compreendermos o movimento do seu pensamento estético. Nesse sentido, acreditamos que as estéticas de juventude e de maturidade do autor são fundamentadas por influências teóricas diversas, as quais apontam para um pensamento estético marcado pelo profundo rompimento do Lukács maduro, autor da Estética (1963), para com o jovem Lukács, da Filosofia da Arte (1912-1914) e da Estética de Heidelberg (1916-1918). 


\section{Bibliografia}

" Bastos, H. (2016). "Ficcional e Verídica: Notas sobre a historicidade da poesia". En Revista Letras, núm. 94, pp. 87-103. Curitiba: UFPR.

"Cases, C. (1985). Su Lukács: Vicende de un'interpretazione. Turín: Giulio Einaudi editore s.p.a.

"Lukács, G. (1964). Ensaios sobre literatura. Río de Janeiro: Civilização Brasileira.

" Lukács, G. (1972). Estetica, vol. 2. Barcelona: Grijalbo.

" Lukács, G. (1973). Filosofia dell'arte (1912-1914). Milán: Sugare Editore \& C.

" Lukács, G. (1974). Estetica di Heidelberg (1916-1918). Milán: Sugare Editore \& C.

" Lukács, G. (1978). Introdução a uma estética marxista. Río de Janeiro: Civilização Brasileira.

" Machado, C. E. J. (2004). As formas e a vida. San Pablo: Editora UNESP.

"Marx, K. (2004). Manuscritos econômico-filosóficos. San Pablo: Boitempo.

"Patriota, R. (2010). A relação sujeito-objeto na Estética de Georg Lukács: reformulação e desfecho de um projeto interrompido. Tese (Doutorado) - Faculdade de Filosofia e Ciências Humanas, Departamento de Filosofia, Universidade Federal de Minas Gerais.

"Perlini, T. (1968). Utopia e prospettiva in György Lukács. Bari: Dedalo Libri.

"Tertulian, N. (2008). Lukács: Etapas de seu pensamento estético. San Pablo: UNESP.

"Vedda, M. (2006). "Vivencia trágica o plenitud épica: un capítulo del debate LukácsAdorno". En La sugestión de lo concreto. Estudios sobre teoría literaria marxista. 195213. Buenos Aires: Gorla. 